\title{
Content Analysis of Ethics of Governance, Maladministration and Political Corruption
}

Igwe, P. A., Egbo, O. P., Nwakpu, S. E., Hove-Sibanda, P., Mohammad Saif, A. N. \& Islam, M. A (2021), Content Analysis of Ethics of Governance, Maladministration and Political Corruption. International Journal of Public Sociology and Sociotherapy, Vol. 1, Issue 2, pp. 15-32 July-December 2021. https://doi:10.4018/IJPSS.2021070102

\begin{abstract}
Although different forms of corruption exist in every regions, Africa, South America, Latin America, Russia, and Asia countries, perhaps to a greater extent engage in higher levels of corruption more than other regions of the world. Applying ethics of governance and theory of "Patrimonialism", this article examines governance of ethics and corruption. This article argues that corruption lays the foundation for the abridgement of citizens' rights and perpetuation of underdevelopment. Methodologically, we explored contents through multiple media sources, ensuring rigor and trustworthiness. Our findings reveal how corruption is being perpetuated in Nigeria, prosecuted and the challenges. This article finds a strong relationship between corruption, the absence of ethics of governance, and maladministration. Many public and political office holders engage or support corruption, there is lack of moral and ethical considerations. More so, it appears that politics is based on wealth acquisition, self-interest rather than on ideologies.
\end{abstract}

Keywords: Administrative Corruption; Political Corruption; Ethics of Governance; Patrimonialism; Qualitative Content Analysis; Nigeria

\section{Introduction}

The ethics of governance revolves around the question: "in whose interest should a corporation be governed?" (Rossouw, 2020, p. 187). The ethics of governance is about the incorporation of moral conditions and requirements in the management, governance, and control structures of organizations (Wieland, 2001). In developed economies, there has been a quite drastic evolution in both the prominence and positioning of ethics (Rossouw, 2020). However, the failure of corporate governance and governance of ethics in many developing countries threaten political, administrative, and developmental progress (Adegbite, 2010; Armstrong, 2003; Rossouw, 2005). Contrasting the trajectory of corruption in Africa with Latin America, 
South East Asia, Russia and Central Asia, "patrimonialism and neopatrimonialism have been associated with greater axiological neutrality than in Africa due, inter alia, to the preservation of an analytical dichotomy between regulated and predatory forms of neopatrimonialism" (Bach, 2011, p. 275).

Against this background, this article examines the forms and the impact of corruption on Nigerian developmental progress. Corruption violates a nation's secular values and represents a repressive moral code. Corruption has been blamed for the failure of governance in many developing countries (Steytler, 2020; Igiebor, 2019; Walton, 2015; Elliott, 2012; Kaufmann et al., 2007). Corruption is often referred to as the abuse of public office for private gain (Walton, 2015). The challenge facing corruption analysts begin how to define it (Elliott, 2012). Of course, corruption is not just a problem for developing countries (Elliott, 2012). Among the numerous problems facing Nigeria in the 21st century despite being "the Giant of Africa", African most populated country and the continent's biggest economy is the bad image, which is rightly or wrongly portrayed by the Corruption Perception Indices orchestrated under the framework of the global Transparency International (see, e.g., Madichie, 2005; Ochulor, 2011).

Studies on the history of corruption in Nigeria describes the relationship between colonisation and corruption/patrimonialism, as well as the manifestations of corruption during authoritarianism and the democratisation process (Martini, 2014). Evidence suggests that there is an apparent rise in corruption following democratisation (Igiebor, 2019; Madichie, 2005). Nigeria is the 146 least corrupt nation out of 180 countries in 2019 , according to the Corruption Perceptions Index reported by Transparency International (2020a). The challenge facing corruption analysts begin how to define it, hence, many developing nations are struggling to legislate and define corruption in their constitution.

The types of corruption include (i) presidentialism, i.e. the systematic concentration of power on the hands of one individual; (ii) use of state resources for political legitimation; (iii) a culture of "rent-seeking" linked to the private appropriation of resources by a particular group; and (iv) systematic clientelism, where power is maintained through the awarding of personal favours, such as public jobs, contracts and licenses, among others (Erdmann \& Engel, 2007, cited in Martini, 2014, p. 2). As a theoretical lens, this article applies Max Weber "patrimonialism" that describes a system where decisions about policies and resources are made by powerful politicians and their cronies who are linked by informal, personal and clientelist networks that co-exist with the formal state structure (Nawaz, 2008, cited in Martini, 
2014). Neo-patrimonial states fail to guarantee the universal and fair distribution of public resources (Martini, 2014). The critical questions for this study include:

- What are the definitions of political and administrative corruption?

- What forms does corruption take place in the political and administrative system?

- What extent is corruption investigated and prosecuted and the challenges?

Governance from a sociological perspective is an interesting subject that addresses a wide range of issues including social, economic, and political continuity, security and integrity, individual and collective safety, the liberty and rights of citizens (Fox \& Ward, 2008). The current study contributes to the scope of administrative and political corruption by exploring the definition, forms of corruption and integrating real cases (through content analysis) but also highlighting the extent and how corruption is a significant challenge to Nigerian development. As recommended by Kooiman (1999) interactive or social-political governance is necessary that enable first-order governance (which means problem-solving and opportunity-creation), and second-order governance, (which examines the institutional conditions and metagovernance) which deals with the principles which 'govern' governance itself.

\section{Literature Review and Theoretical Frame}

\section{The ethics of governance}

The governance of daily life poses both practical challenges and theoretical questions about balances between the rights, concerns and values of individuals, the state, commerce, professions (Fox \& Ward, 2008). Globally, comparative corporate governance scholarship has continued to pay attention to the convergence of national systems of corporate governance (Adegbite, 2010). On the African continent, this phenomenon is evident in the number of national corporate governance reports that have been produced (Rossouw, 2005). There are no agreed definitions or boundaries for investigating corporate governance (Adegbite, 2010). Ethics is the guiding principles by which behaviour (standards of right and wrong and prescribe what public servants ought to do) are evaluated in the private or public sector. Corporate governance is an aspect of ethics which refers to the set of systems, principles and processes by which organizations are governed.

Within the framework of good corporate governance, accountability is the obligation of public or private officials and leaders to account for their activities, accept responsibility, 
and to disclose results transparently. However, the developments in corporate governance globally in the past three decades have been spurred by all too frequent instances of spectacular governance failure and corporate scandal (Kana, 2020). Rossouw (2020) maintains that governance of ethics focuses on the role and responsibilities of governing bodies for the ethical conduct and decision-making of governing bodies themselves, but also for the organisations that they govern.

Despite the diversity among the 53 countries with their varied colonial legacies constituting Africa, some patterns can be discerned regarding corporate governance (Rossouw, 2005, p. 94). According to Kana (2020), a timeline of foundational governance developments over this period casts some doubt on the efficacy of rules-based attempts to curb the worst excesses of corporate behaviour. Therefore, "governance of ethics role and responsibility would typically entail that the governing body exercises oversight of the ethical conduct and decision-making of the governing body and the organisation that it governs, that it approves ethical standards in the form of codes or policies, and that it provides strategic direction for the ethical conduct and culture of the organisation (Rossouw, 2020, p. 187).

\section{A neo-patrimonial state}

Max Weber (1864-1920) as social theorists and sociological analysts for more than a century produce several formulations, contributions, and original insights in the discussion of concepts such as rationalization, charisma, legitimacy, class, status, power, and bureaucracy (Curtis, 2009). The concept of patrimonial domination was at first underutilized in western social science (Maslovski, 1996). "Patrimonialism" is a form of political organization in which authority is based primarily on the personal power exercised by a ruler, either directly or indirectly (Baker, 2017). Another definition is provided by Martini (2014, p. 2) as a social and political order where patrons secure the loyalty and support of clients by granting benefits from their own or state resources. The notion of identity and substantive liberty reflects a perspective on human agency that acknowledges the interconnection of the social and non-social and links sociological understanding of agency with political philosophy (Woods, 2003).

In patrimonial states, decisions about policies and resources are made by powerful politicians and their cronies who are linked by informal, personal and clientelist networks that co-exist with the formal state structure (Martini, 2014). Neo-patrimonial states fail to guarantee the universal and fair distribution of public resources (Martini, 2014). In his remark, Bach (2011) posits that endorsing the concept of patrimonialism in the early 1960s was restrained by a deep ambivalence towards ways of conceptualising it in so-called modern states and 
solving the issue was achieved through the introduction of a dichotomy between 'traditional' and 'neo-traditional' regimes (Bach, 2011). Economists have come to recognize that corruption is not just an aberration or a nuisance; it is a systemic feature of many economies, which constitutes a significant impediment to economic development (Azfar, Lee \& Swamy, 2001).

\section{Forms of corruption}

Public opinion differs so much from formal definitions of corruption (Walton, 2015; Elliott, 2012; Peters, 2018). Many developing nations are struggling to legislate and define corruption in their constitution. Malawian Corruption Practice Act 18 of 1995, s2(2) states as follows:

[Corruption is] the offering, giving, receiving, obtaining or soliciting of any advantage to influence the action of any public officer or any official or any other person in the discharge of the duties of the public officer, official or other persons (Steytler, 2020, $p$ 19).

Corruption has also been viewed from the perspective of the principal-agent problem in which the latter motivates himself to favour a third party at the expense of the former (principal) in exchange for an illegal compensation (Madichie, 2005). Corruption may amount to discrimination and unequal treatment (Peters, 2019). Corruption had penetrated virtually every agency in the public sector in Nigeria (Madichie, 2005; Ijewereme, 2015). Some studies provide a nexus between corruption and money laundering by highlights the corruption risks hidden in designated non-financial business and professionals, and the risks of laundering the proceeds of corruption by politically exposed persons and financially exposed persons (Ai, 2013). Ijewereme, (2015, p. 3) provide a list of behaviors regarded as forms of political corruption in Nigeria: acceptance of gratification; succumbing to inducement and undue influence; embezzlement; conflict of interests (for example, the award of contracts by public office holders to cronies, family members, and personally held companies) bribery and fraud.

Other forms include nepotism and tribalism in recruitment/appointment and promotion, kickback on contract, rigging of elections, misappropriation and conversion of public funds for personal gains, procurement scam, diversion and misappropriation of funds through manipulation or falsification of financial records; payment for favourable judicial decisions, money laundering and so on (Ijewereme, 2015). Budgeting Corruption (where management of a public organization in connivance with a governing council or board minister/commissioner bribes some members of the legislature to approve inflated estimate for the institution during budgeting) (Cimpoeru \& Cimpoeru, 2015). 


\section{The Context: Background on narratives of corruption in Nigeria}

Nigeria "the Giant of Africa" is African biggest economy. Since independence in 1960, Nigeria has experienced several challenges in the administration and governance of public and private sectors. However, since the return to democratic rule in 1999, the ethics of governance, corruption and insecurity has become the greatest challenges to economic progress. Corruption is so pervasive in Nigeria that it has turned public service for many into a kind of criminal enterprise (Human Right Watch, 2011). Like many other, if not all, countries in Africa have adequate definitions of the crime of corruption, loosely defined as the abuse of public office for private gain (Steytler, 2020). Among the major institutional problems that have impeded sustainable development in Nigeria is corruption, which appears embedded in the culture (Igwe, 2020; Igwe et al., 2020; Okolie, Igwe \& Elom, 2019). It is estimated that over $\$ 400$ billion of the Nigerian oil revenue has either been stolen or misappropriated since Nigeria gained independence in 1960 according to the former Vice President for Africa of the World Bank, Dr Oby Ezekwesili (see, e.g., Okoye, 2012).

Evidence demonstrates that corruption in Nigeria serves two main purposes: (i) to extract rents from the state, which includes forms of corruption such as embezzlement, bribery, nepotism and cronyism, among others; and (ii) to preserve power, which includes electoral corruption, political patronage, and judicial corruption (Martini, 2014). Economic and Financial Crimes Commission (EFCC) is the agency responsible for charging and convicting corruption cases in Nigeria. Soon after it was established in December 2002, the EFCC began pursuing corruption cases in a way that publicly challenged the ironclad impunity enjoyed by Nigeria's political elite (Human Right Watch, 2011). Although EFCC has succeeded in prosecuting some politicians since its inception, many of the corruption cases against the political elite have made little progress in the courts (Onyema et al., 2018).

Human Right Watch (2011) explains that not all the prosecution failures are down to the agencies responsible like EFCC. There are enormous institutional hurdles to any honest effort to prosecute corruption in Nigeria (Human Right Watch, 2011). Citizens may be more likely to engage in or support corruption. At a fundamental level, Nigeria's political system continues to reward rather than punish corruption. There was also a welcome party to receive an ex-governor from Nigeria after being released from UK jail for $\$ 250 \mathrm{~m}$ corruption charges. His residence was besieged by well-wishers and political associates in the state in jubilations (Punch, 2017). The message was unmistakable - proven criminality is no bar to the highest echelons of politics in Nigeria (Human Right Watch, 2011). 
Komolafe, Nkereuwem and Kalu-Amah, (2019) maintain that Nigerians continue to bear the political, economic and social effects of corruption and money laundering. A former World Bank Vice President, Dr Obiageli Ezekwesili estimated that about US\$400 billion of Nigeria's oil revenues had been 'stolen' or misspent since Nigerian independence (Onyema et al., 2018). General Sani Abacha was a Nigerian military President from 1993 until he died in 1998. Transparency International states that the extent of Abacha corruption became public only after his death when it emerged that he took between US $\$ 3$ and $\$ 5$ billion of public money. Nigeria has received more than $\$ 300 \mathrm{~m}$ ( $£ 241 \mathrm{~m}$ ) that were stolen by the former military ruler, under the US and the British - Jersey repatriation agreement (BBC, 2020).

One would be forgiven to think that Nigerians swim in richness, but no, majority of the population are poor and lack access to necessities such as food, clean water, roads, electricity, basic health care, basic education, etc. (Igwe et al., 2020). According to the World Economic Forum (WEF, 2019), African highest oil producer has about 90 million people - roughly half its population - living in extreme poverty (those living on less than $\$ 1.90$ per day). Arguably, corruption, high rate of unemployment and poverty are linked to insecurity. Terrorist group Boko Haram based in North-western region, high rate of kidnapping for ransom, armed bandits terrorizing many states and armed Fulani herdsmen clashing with local farmers over grazing land has degenerated beyond the control of internal security forces. These factors remain the greatest threat to the unity and economic progress of Nigeria. Despite these challenges, Nigerians are among the most successful ethnic groups and globally their successes can be seen in academics, science, technology, music, sports, international politics, and the diaspora.

\section{Methodology}

This study applies Qualitative - Content Analysis (CA) method. CA is a qualitative research method used to interpret the content of text data through a systematic classification process involving coding and identifying themes (Collins et al., 2018). This method is a widely used qualitative research technique (Hsieh \& Shannon, 2005; Igwe, Lock \& Rugara, 2020). The CA perspective has been widely exerted in several previous studies to yield anti-corruption information from annual reports (Joseph et al., 2016; Branco \& Matos, 2016). CA identifies patterns in recorded communication that enable researchers to systematically collect data from a set of texts, which can be written, oral, or visual. The purpose of CA is to organize and elicit meaning from the data collected and to draw realistic conclusions from it (Bengtsson, 2016). To examine the core research questions, this study presents an investigation of the content of 
online news outlets, covering corruption in Nigeria, published on the main page of the online editions.

Bengtsson (2016) describe four distinct main stages: the decontextualisation, the recontextualisation, the categorization, and the compilation process. Analytic steps include (1) formulating a testable research question; (2) establishing what items will be analysed; (3) defining mutually exclusive variables central to the analysis; (4) piloting and refining the coding frame; (5) coding the data; and (6) interpreting the findings and writing the report (Hodgetts \& Chamberlain, 2014). Integrating Bengtsson (2016) and Hodgetts \& Chamberlain (2014) which we have extended to Five stages of "Qualitative - Content Analysis Process" that guided this study in collecting and analysing data. The steps that we followed are outlined in the process stages (Figure 1).

\section{[INSERT FIGURE 1 HERE]}

CA demonstrates how automated approaches can access both semantic and stylistic properties of content (Flaounas et al., 2013). In conventional CA, coding categories are derived directly from the text data (Hsieh \& Shannon, 2005). As validation process, we verified each case through analysing different media. Only cases published by more than one media source has been presented as findings. Some of the merits of CA include directly examines communication using text, allows for both qualitative and quantitative analysis and provides valuable historical and cultural insights over time (Hsieh \& Shannon, 2005). Some of the disadvantages include, it can be extremely time consuming and could be subject to increased error, particularly when a relational analysis is used to attain a higher level of interpretation (Elo et al., 2014). Finally, there is the possibility of bias conclusions of the qualitative characters.

\section{Analysis}

This section provides an overview of the existing evidence on the main types of corruption in Nigeria, the extent of corruption based on media reports. Thematically, we have separated the cases into (i) rent-seeking, (ii) embezzlement and money laundering, (iii) conflict of interest, and (iv) bribery and kickbacks. 


\section{Rent-seeking}

Politicians, public servant, and contractors using their positions to extract as much as possible from the state (through fraudulent practices) or people being interested in getting a larger share of the state wealth without contributing to the growth of the Nigerian economy.

"Nigerian government uncover a total of 60,000 ghost workers in federal establishments across the country following the staff audit of the federal government ministries, departments and agencies (MDAs) on the implementation of the Integrated Personnel and Payroll Information System (IPPIS), saving the government over N160 billion (approx. US\$9 billion) (All Africa, 2014)”.

"EFCC probes State Government 4 Accounting officials of N117bn cash withdrawal in 3 years. In one fell swoop and precisely on June 8, 2015, a total of 45 different cheques in the amount of N10 million each amounting to N450 million were issued and cashed over the counter in the name of one person. "The following day, that is June 9, 2015, 50 different cheques amounting to N500 million were issued in the name of another person and withdrawn over the counter of the same bank." (Vanguard 2018).

"Nigeria's ex-security adviser 'arrested over \$2bn arms fraud" (BBC, 2015).

These are evidence of how corruption has permeated deep into government ministries and agencies. As a result, the Nigerian government has introduced the Treasury Single Account (TSA) maintained by the Central Bank of Nigeria and into which all revenue and income of the government are remitted to maintain transparency. Also, Bank Verification Number $(\mathrm{BVN})$, (a unique bank identification number linking an individual to his various bank accounts) helps with the gathering of financial intelligence data to curb private-sector fraud (Vanguard, 2015).

\section{Embezzlement and money laundering}

This refers to "the misappropriation of property or funds legally entrusted to someone in their formal position as an agent or guardian (Martini, 2014, p. 5). In 2016 a former national security adviser to former Nigerian President was arrested and accused of misappropriating funds meant for the purchase of arms and equipment in the country's fight against Boko Haram. According to media reports, the sum involved was $\$ 2.1$ billion (Lexology, 2016; BBC, 2015). 
Arguably, majority of Nigerian politicians and public office holders has lost their moral and ethical considerations. Embezzlement is another form of corruption which borders on criminal breach of trust and misappropriation of public funds.

A Federal High Court, sitting in Lagos ordered permanent forfeiture to the Federal Government of a $\$ 37.5 m$ skyscraper on the highbrow Banana Island, Lagos, belonging to former Minister. Estate, which is said to have 24 apartments, 18 flats and six penthouses. The Presiding Judge [...], also ordered that the sums of \$2,740,197.96 and N84,537,840.70 realised as rents on the property should also be forfeited to the Federal Government (Vanguard, 2017).

The EFCC told the judge that its investigations revealed that the ex-minister bought the property sometime in 2013 at the price of $\$ 37.5 \mathrm{~m}$ and paid for it in cash. According to the EFCC, the \$37.5m was moved straight from the ex-minister's house in Abuja and paid into the seller's bank account in Abuja. "Nothing could be more suspicious than someone keeping such huge amounts in her apartment. Why was the ex-minister doing that? To avoid attention" (Vanguard, 2017).

“JAMB revenue officer allegedly stole N36.5m - EFCC witness. An EFCC witness, [...] told an FCT High Court, N36.5 million was not remitted to the Joint Admission and Matriculation Board (JAMB) as revenue. The EFCC charged a JAMB revenue officer who once claimed in 2018 that a snake swallowed the money in her custody and her boss, the state coordinator in Makurdi office, with eight counts bordering on conspiracy, breach of trust and misappropriation" (Vanguard, 2020).

"Nigeria's anti-corruption agency has arrested three former state governors for allegedly embezzling funds amounting to $\$ 615 \mathrm{~m}$ (£400m), each accused of $\$ 387 \mathrm{~m}$, $\$ 167 m$ and $\$ 120 m$ fraud allegations. During their time in office, the men are alleged to have abused state contracts and diverted government money for their personal use" (BBC, 2011).

EFCC has successfully prosecuted some big cases of corruption which led to some politicians going to jail, either after being convicted such as serving senator and former governor of 
Plateau state accused of embezzling N1.162 billion ecological funds belonging to his state, a former Taraba state governor, found guilty of diverting N1.64 billion while he served as governor between 1999 to 2007. Another case involved a former governor between 2007 and 2015 charge with diverting N6.3bn alongside a former cashier in the office of the Secretary to the State Government and several other cases concluded or pending in the courts.

\section{Conflict of interest}

Conflicts of interest represent circumstances in which professional judgments or actions regarding a primary interest, such as the responsibilities of an officer, maybe at risk of being unduly influenced by a secondary interest, such as financial gain or non-financial gain (Romain, 2015). An ex-Minister has been accused of receiving \$336m from a deal. The [....] deal is Nigerian corruption trial in Italy, where a Nigerian ex-Minister is an accused, together with alleged two middlemen, some companies, and several of their executives" (Finance Uncovered, 2020).

"The Nigerian authorities have also charged the ex-minister and several others linked to [......] deal with money laundering in connection with the onward flow of funds from the [....] deal. The ex-minister is alleged to have paid a total of $\$ 57 \mathrm{~m}$ for a jet in 2011. It has a range of up to 6,000 nautical miles and a luxurious interior for 17 passengers. The jet was part of an epic spending spree the ex-minister is said to have embarked on after allegedly receiving $\$ 336 m$ from the [......] deal” (Finance Uncovered, 2020).

"As Nigerian minister in the last weeks of the Abacha military regime in 1998, the exminister had effectively awarded the prospecting rights to the huge [.......] deal with a company he secretly controlled, [......] company" (Finance Uncovered, 2020).

After President Abacha's sudden death, the ex-minister retained the rights as a private citizen until he offloaded them to oil giants [...] and [...] in 2011, who paid a combined $\$ 1.3$ billion to the Nigerian government. Investigators allege some $\$ 336 \mathrm{~m}$ then trickled down to the ex-minister via several bank accounts, and that one of the first payments he made, \$54m, was the main instalment on this jet (Finance Uncovered, 2020). 
Ethics of good governance in public organisations recognise the need to have arrangements in place that prevent or deal with potential conflicts of interest. Conflict of interest takes the form of using proxy and/ or award of contracts to companies where an individual has an interest. Another interpretation is when someone's judgement or actions (independence or impartiality) at work could be affected by something unconnected with their role.

On December 5, 2019, EFCC secured the conviction and sentencing of a former governor of [....], to 12 years imprisonment for an N7.65bn fraud before Justice [....] sitting at the Federal High Court in Ikoyi, Lagos. "This case started in 2007 and the convicts filed a series of applications to stall this case (EFCC, 2019).

The State Government funds running into some billions of Naira in various Banks were allegedly fraudulently withdrawn and illegally converted into drafts in favour of the personal use of the Appellant in his [.....] GROUP of Companies (NigeriaLII, National Judicial Institute 2016).

Other allegations levelled against the Appellant were that he awarded the State Governments contracts to such companies as [...] Construction Ltd, [....] Construction LTD, [....] Nigeria LTD and [....] Nigeria LTD in which he had an interest. It was alleged that the contractors to whom contracts were awarded by the Appellant as the Governor, also obtained several bank drafts which were lodged into the accused account as gratifications (NigeriaLII, National Judicial Institute, 2016).

On May 8, 2020, the Supreme Court quashed the 12-year jail term slammed on the former governor, his firm and former Director of Finance based on technical grounds and EFCC is set to start a retrial after 7 years (see, Nigeria Tribune, 2020, May 8). Here is another landmark case of political corruption:

"The money laundering conviction and 13-year prison term for the Nigerian politician and former governor on April 17, 2012, is a landmark in the global fight against corruption. The ex-governor [....] pleaded guilty in a London court to charges involving more than $\$ 79$ million. For many years one of Nigeria's most powerful and wealthy politicians was governor of [...] in the oil-rich Niger Delta. During [...] eight years in office, from 1999 to 2007, the state government received several billion dollars in oil revenue" (HRW, 2012). 
"Among of EFCC high profile case and the convict was [....] was convicted in July 2007. The process of the disposal of his forfeited asset also commenced the same year following his conviction. [...], a former governor of a Nigerian state gained notoriety for building extravagant public works and embezzling as much as $\$ 55$ million in Oil Ministry revenue, spending it on luxuries and homes around the world" (New York Times (2015)

\section{Bribes and kickbacks}

Corporate bribery is defined as the practice of paying government officials for preferential treatment (Montero, 2018). Financial bribery and kickbacks are characteristics of corruption that are considered a serious threat to developing countries like Nigeria.

EFCC demanded the extradition from the UK of a former petroleum minister accused of helping to loot billions of dollars from the nation's coffers. Days later the financial crimes watchdog charged a former attorney-general with allegedly taking bribes to allow a \$1.3bn oil block deal in 2011 (Financial Times, 2020).

"A Nigerian [....] has forfeited a princely sum of N426.7million to the Federal Government on the orders of a Federal judge, sitting in Lagos". The first respondent was a salary earner and a public officer with an estimated monthly salary of about N750,000 and could not have ordinarily raised such amount of money in one fell swoop. The first respondent was an officer of the [...], while the second respondent, [...] Venture, was a business name owned and incorporated by him in a bid to use same and commit the crime" (Vanguard, 2020).

Bribes and kickbacks are common forms of corruption in the civil service and law enforcement agencies (like Police, Custom and Immigration), Judiciary, Parliament and Electoral Agencies. Bribes, kickbacks, and corruption are commonly used to get things done in one's favour or approved quicker, get the connection of public utilities and infrastructure. Studies show that bribes and kickbacks are counterproductive (Montero, 2018). 
Nigeria's anti-graft agency, the Economic and Financial Crimes Commission (EFCC), has frozen accounts containing $\$ 31.4$ million controlled by the former first lady who claims some of the money was for payment of medical bills (Quartz Africa, 2016).

Nepotism and cronyism (such as political patronage and budgeting corruption) are other forms of corruption that negative impact on Nigerian economic development. In prosecuting corruption cases, opposition party accuses the ruling government of targeting political opposition and being selective (Mordi, 2016). A study by Cimpoeru \& Cimpoeru (2015) found that the Open Budget Index (OBI) and GDP per capita has a positive and significant effect on the level of corruption control in all countries. OBI improves government policies as well as providing vital information to the public (Cimpoeru \& Cimpoeru, 2015).

There are several challenges in the prosecution of corruption cases in Nigeria. Onyema et al., (2018) cite weakness of the institution and the failure of the EFCC to conduct thorough criminal investigations and the resulting inadequacies of criminal prosecutions that are struck out on technicalities. The police force, courts and the legal system can be an obstacle to prosecuting corruption (Human Right Watch, 2011).

"When the EFCC brought 170 criminal counts against former governor [...], a judge sitting in [...] home state threw out every single count-including evidence that [...] paid EFCC officials $\$ 15$ million in an attempt to influence the outcome of the investigation (Human Right Watch, 2011).

Other corruption obstacles include delays and injunctions from prosecutions. A case delay can be defined as "the time taken, other than that required to properly obtain, present and weigh the evidence, law and arguments" (GSDRC, 2016: 1). Delays and adjournments are often called by lawyers using tactical procedures or willingly reluctant to provide full information on evidence to cause a delay or adjournment. Lawyers also obtain injunctions from courts to restrain law enforcement agencies from prosecuting their clients.

“A two-term former governor of one of the Niger-Delta states between 1999 and 2007, was accused by the EFCC of misappropriating public funds to a tune of N100 billion while he was governor. In February 2007, the governor approached the Federal High Court in Port Harcourt, praying it to grant him an order preventing any law enforcement agency from arresting and prosecuting him for fraud. On March 23, 2007, 
Justice [...] granted the former governor an injunction, restraining the EFCC from any further action about the alleged economic and financial crimes (Premuim Times, 2020).

Also, prominent lawyers try to influence judges to win cases. A pilot survey in 2020 by the Independent Corrupt Practices (ICPC) and Other Related Offences has found that estimated N9.4bn bribes exchanged hands in the judicial sector between 2018 and 2020 (see, e.g., Sanni, 2020). Of the 901 respondents in the survey, 638 making 70.81 per cent were lawyers. Judges were 124 judges or 13.76 per cent, and 25 respondents at 2.77 per cent were court staffs (clerks and registers). The study found that the level of corruption in the justice sector was heightened by the "stupendously high amounts of money offered as bribes to judges by lawyers handling high electoral and political cases" (Sanni, 2020).

Two Judges in EFCC Net over Bribes from Lawyers. "Two Federal High Court judges [....] and [....] have reported to the EFCC. The EFCC on March 9, 2016, arraigned two senior lawyers [....] and [....] before a Lagos High Court on allegations of bribery and offering gratification to a public official (Thisday, 2016).

Against these backdrops, most of the EFCC's cases against prominent politicians have been stalled in the courts for years without the trials even commencing (Human Right Watch, 2011). Table 1 presents some of EFCC High Profile Corruption Cases between 2006 - 2015.

[INSERT TABLE 1 HERE]

\section{Discussion}

While global governance developments have been largely characterised by political and regulatory intervention in reaction to failure (Kana, 2020), the fundamental governance of ethics has eluded Nigeria, at least in practice. Studies on the impact of corruption are mixed. Some types of corruption have a greater negative impact on specific aspects of economic development (Anderson, 2015). Across Africa, neopatrimonialism is still classically viewed as the outcome of confusion between office and officeholder within a state endowed, at least formally, with modern institutions and bureaucratic procedures (Bach, 2011, p. 277). Corruption is Nigeria's worst problem. Corruption in Nigeria is responsible for all kinds of 
woes, such as election rigging, failed promises, abandoned public projects, poor quality of implemented projects, dilapidated infrastructure, nepotism, instability, insecurity, high rate of unemployment etc (Ijewereme, 2015).

In the development of governance prescripts, the systematic process of aligning company law, regulation, standards and codes to the constitutional framework has not been fully developed to tackle the challenges of governance of ethics. An illiberal democracy (denotes partial democracy, flawed democracy, empty democracy or guided democracy), a governing system in which although elections take place, citizens are cut off the outcome or the result through election corruption and politicians are never held to account based on their political campaign promises. Gillanders (2014) found that countries with more corruption tend to have worse infrastructure. There is also another dimension - the relationship between corruption and subjective wellbeing. Previous studies have found that experienced corruption undermines individual wellbeing for both bribe victims and recipients (Sulemana, Iddrisu \& Kyoore, 2017).

Nigeria is assessed as a neo-patrimonial state, where power is maintained through the awarding of personal favours and where politicians abuse their position to extract as many rents as possible from the state (Martini, 2014). Overall, corruption is bad for inequality and poverty (Andres \& Ramlogan-Dobson, 2011). Through the payment of bribes, some individuals succeed in getting favourable treatment which reduces the costs for the economic activities in which the individuals are engaged. The weakness of the system of governance ensures that corruption is perpetually recycled when such needless rigmarole could have been nipped in the bud. Studies suggest, however, that citizens' demand for punishment of corrupt government officials are weak and not credible (Yap, 2013). In the case of Nigeria, most citizens will not report cases of corruption, would support corruption or engage in corruption to get things going or influence a decision in their favour. In most cases, citizens are likely to defend or protect those being persecuted or investigated with corruption.

\section{Conclusion and Implications}

The high rate of corruption, maladministration, and lack of ethics of governance pose the greatest challenges to Africa's most populated country (Nigeria). Corruption has a negative effect on economic and human development progress. Corruption lay the foundation for the abridgement of citizens' rights and perpetuation of underdevelopment and poverty in Nigeria. The most challenge is in defining, reporting, monitoring, identifying and prosecuting cases of corruption. Taking ethics of governance approach and shifting the governance paradigm to 
ethical leadership is critical to good governance. Power relations can be addressed by building capacity, synergy and trust. When discussing accountability and transparency, most studies explore the corruption of individuals and corporate bodies as a responsibility mechanism regarding the behaviour of public officials and corporate organisations. It does appear when it comes to corruption, Nigeria acts like Pluralist State (the recognition and affirmation of diversity within a political body), which is seen to permit peaceful coexistence of different orientations, ideological convictions, and corruption interests.

It seems that most Nigerian citizens may be more likely to engage in or support corruption and weakness of the system of governance ensure that corruption is perpetually recycled. The implication is that if citizens are not concerned about corruption, they will be less likely to report it as a crime. Besides regular governance failures, the lack of accountability and transparency is one of the main reasons for the under-development of many African economies. Lack of accountability exists in several forms and at various levels: the lower, middle and upper levels of society. The prevention and prosecution of corruption have several implications. The financial savings accruing from lack of corruption could be channelled into developing infrastructure (electricity, road and water), education, health care and industrial development. How corruption is investigated or prosecuted help to allay the public notion about corruption and public trust (McAllister, 2014).

Eliminating corruption will enable accountability and transparency in public service delivery and reporting. Minimizing political corruption will enable ordinary citizens to participate in the running of their country, and the effect it would have on politics and government would be transformative (Dunlop, 2018). Concerning implications for research, more studies are required to highlight the effect of corruption in African countries like Nigeria. There is a lack of studies focusing on the forms of corruption with real cases. Without the public understanding of the impact that corruption has on their lives and economic development of their nation, anti-corruption practices may be ineffectual.

If citizens are not concerned about corruption, they will be less likely to report the crimes (Walton, 2014). Besides, the way citizens perceive corruption is likely to affect how they behave themselves (Walton, 2014). Research is required to address how governance can be achieved and sustained within a social context imbued with cultural values (Fox \& Ward, 2008). Finally, more studies are required to understand and explore the economic model of corruption and its relationship to legal institutions, political institutions, and firms (Bahoo et al., 2020; Igwe et al., 2020). We advocate for a dynamic and responsive governance and a system of corporate governance to social and economic development. 


\section{References}

Adegbite, E. (2010). The determinants of good corporate governance: The case of Nigeria. Doctoral Thesis, Cass Business school, City University.

All Africa New (2014). Nigeria: FG Uncovers 60,000 Ghost Workers, 22 October 2014. https://allafrica.com/stories/201410220230.html

Ai, L. (2013). A cost-effective strategy of implementing international anti-corruption initiatives: Enhancing the role of anti-money laundering in combating corruption", Journal of Money Laundering Control, Vol. 16 No. 1, 83-90.

https://doi.org/10.1108/13685201311286887

Alon, I., Li, S., \& Wu, J. (2016). Corruption, Regime Type, And Economic Growth. Public Finance and Management, 16(4), 332-361

Armstrong, P. (2003). Status report on corporate governance reform in Africa. Johannesburg, South Africa: Pan-African Consultative Forum on Corporate Governance.

Anderson, B. B. (2015). Corrupting activities and economic development, World Journal of Entrepreneurship. Management and Sustainable Development, 11(1), 64-70.

https://doi.org/10.1108/WJEMSD-07-2014-0020

Andres, A. R., \& Ramlogan-Dobson, C. (2011). Is Corruption Really Bad for Inequality? Evidence from Latin America. The Journal of Development Studies, 47(7), 959-976 DOI: $\underline{10.1080 / 00220388.2010 .509784}$

Azfar, O., Lee, Y., \& Swamy, A. (2001). The Causes and Consequences of Corruption. The ANNALS of the American Academy of Political and Social Science, 573(1), 42-56 https://doi.org/10.1177/000271620157300103

Bach, D. C. (2011). Patrimonialism and neopatrimonialism: comparative trajectories and readings. Commonwealth \& Comparative Politics, Vol. 49, No. 3, pp. 275-294

DOI: $\underline{10.1080 / 14662043.2011 .582731}$

Bahoo, S., Alon, I., \& Paltrinieri, A. (2019). Corruption in International Business: A Review and Research Agenda. International Business Review, (in Press).

doi:10.1016/j.ibusrev.2019.101660

Bahoo, S., Alon, I., \& Floreani, J. (2020). Corruption in economics: a bibliometric analysis and research agenda. Applied Economics Letters, DOI: 10.1080/13504851.2020.1764476. https://doi.org/10.1080/13504851.2020.1764476

Baker J. I (2017). Patrimonialism. https://www.britannica.com/topic/patrimonialism

BBC (2011). Nigeria's EFCC arrests ex-governors for alleged fraud. October 7, 2011. https://www.bbc.co.uk/news/world-africa-15208522

BBC (2015). Nigeria's Dasuki 'arrested over \$2bn arms fraud' 1 December 2015. https://www.bbc.co.uk/news/world-africa-34973872

BBC (2020). Stolen millions are returned to Nigeria. Africa editor, BBC World Service. Will Ross. https://www.bbc.co.uk/news/topics/cm8m11j59z3t/corruption 
Bengtsson, M. (2016). How to plan and perform a qualitative study using content analysis. NursingPlus Open, 2: 8-14, https://doi.org/10.1016/j.npls.2016.01.001

Branco, M.C., \& Matos, D. (2016). The fight against corruption in Portugal: evidence from sustainability reports. Journal of Financial Crime, 23(1), 132-142.

Cimpoeru, M. V., \& Cimpoeru, V. (2015). Budgetary Transparency - An Improving Factor for Corruption Control and Economic Performance. Procedia Economics and Finance, 27: 579-586, https://doi.org/10.1016/S2212-5671(15)01036-9

Collins, S. E., Taylor, E., Jones, C., Haelsig, L., Grazioli, V. S., Mackelprang, J. L., Holttum, J., Koker, M., Hatsukami, A., Baker, M., \& Clifasefi, S. L. (2018). Content Analysis of Advantages and Disadvantages of Drinking Among Individuals with the Lived Experience of Homelessness and Alcohol Use Disorders. Substance use \& misuse, 53(1), 16-25. https://doi.org/10.1080/10826084.2017.1322406

Curtis, M. (2009). Max Weber: Patrimonialism as a Political Type. In Orientalism and Islam: European Thinkers on Oriental Despotism in the Middle East and India (pp. 258-298). Cambridge: Cambridge University Press. doi:10.1017/CBO9780511812422.010

Dunlop, T. (2018). Voting undermines the will of the people - it's time to replace it with sortition, The Guardian 14 October 2018. https://www.theguardian.com/australianews/2018/oct/14/voting-undermines-the-will-of-the-people-its-time-to-replace-it-withsortition

EFCC (2019). Court Jails Orji Kalu, Bags 12 Years for N7.65bn Fraud.

http://www.efccnigeria.org/efcc/news/5248-court-jails-orji-kalu-bags-12-years-for-n7-65bnfraud

EFCC (2020). Records - What EfCC did with recovered loot. http://www.efccnigeria.org/efcc/what-efcc-did-with-recovered-loot

Elo, S., Kaarianinen, M., Kanste, O., Polkki, R., Utriainen, K., \& Kyngas, H. (2014). Qualitative Content Analysis: A focus on trustworthiness. Sage Open, 4: 1-10.

Elliott, K. A. (2012). Corruption as an International Policy Problem: Overview and Recommendations. Chapter 10. Institute for Economics.

https://www.piie.com/publications/chapters_preview/12/10iie2334.pdf

Financial Times (2015). Unanswered questions on Nigeria's missing oil revenue billions. https://www.ft.com/content/e337c7a4-f4a2-11e4-8a42-00144feab7de

Finance Uncovered (2020). Nigeria seizes luxury private jet linked to OPL245 money laundering in Montreal. June 62020.

https://www.financeuncovered.org/investigations/nigeria-seizes-luxury-private-jet-linked-toopl245-money-laundering-in-montreal/

Flaounas, I., Ali, O. Lansdall-Welfare, T., De Bie, T., Mosdell, N., Lewis, J., \& Cristianini, N. (2013). Research Methods in the Age of Digital Journalism”, Digital Journalism, 1(1), 102-116, DOI: $\underline{10.1080 / 21670811.2012 .714928}$ 
Fox, N. J., \& Ward, K. J. (2008). What governs governance, and how does it evolve? The sociology of governance-in-action. Br J Sociology, 59(3), 519-38. https://doi.10.1111/j.14684446.2008.00206.x PMID: 18782153.

Gillanders, R. (2014). Corruption and Infrastructure at the Country and Regional Level", The Journal of Development Studies, 50(6), 803-819 DOI: 10.1080/00220388.2013.858126

GSDRC (2016). Addressing case delays caused by multiple adjournments. Helpdesk Research Project.

https://assets.publishing.service.gov.uk/media/57a9c983e5274a0f6c000006/HDQ1374.pdf

Hsieh, H.-F., \& Shannon, S. E. (2005). Three Approaches to Qualitative Content

Analysis. Qualitative Health Research, 15(9), 1277- 1288

https://doi.org/10.1177/1049732305276687

Hodgetts, D., \& Chamberlain, K. (2014). Analysing news media, In Flick, U. The SAGE handbook of qualitative data analysis (pp. 380-393). London: SAGE Publications Ltd https://.doi:10.4135/9781446282243

Human Right Watch Organisation (2011). Corruption on Trial? The Record of Nigeria's Economic and Financial Crimes Commission.

https://www.hrw.org/report/2011/08/25/corruption-trial/record-nigerias-economic-andfinancial-crimes-commission

HRW (2012). Nigeria: UK Conviction a Blow Against Corruption. Nigerian Politician Stole Millions, Laundered Fortune Overseas. https://www.hrw.org/news/2012/04/17/nigeria-ukconviction-blow-against-corruption

Igiebor, G. O. (2019). Political Corruption in Nigeria: Implications for Economic Development in the Fourth Republic. Journal of Developing Societies, 35(4), 493-513 https://doi.org/10.1177/0169796X19890745

Ijewereme, O. B. (2015). Anatomy of Corruption in the Nigerian Public Sector: Theoretical Perspectives and Some Empirical Explanations. SAGE Open, 1-15

https://doi.org/10.1177/2158244015581188

Igwe, P. A. (2020). Determinants of Household Income and Employment Choices in the Rural Agripreneurship Economy. Studies in Agricultural Economics, 122(2), 96-103 https://doi.org/10.7896/j.2044

Igwe, P. A., Lock, D., \& Rugara, D. G. (2020). What factors determine the development of employability skills in Nigerian higher education?, Innovations in Education and Teaching International, [Online, Nov. 2020] https://doi.org/10.1080/14703297.2020.1850319

Igwe, P.A., Lock, D., Ochinanwata, C., Nwakpu, E.S., \& Nwedu, C.N. (2020). The global order, regional integration and multiculturally diverse stakeholders: The case of ECOWAS", International Journal of Organizational Analysis, Vol. ahead-of-print https://doi.org/10.1108/IJOA-10-2019-1896

Igwe, P.A., Ochinanwata, C., Ochinanwata, N., Adeyeye, J.O., Ikpor, I.M., Nwakpu, S.E., Egbo, O.P., Onyishi, I.E., Vincent, O., Nwekpa, K.C., Nwakpu, K.O., Adeoye, A.A., Odika, P.O., Fakah, H., Ogunnaike, O.O., \& Umemezia, E.I. (2020). Solidarity and social behaviour: 
how did this help communities to manage COVID-19 pandemic? International Journal of Sociology and Social Policy https://doi.org/10.1108/IJSSP-07-2020-0276

Joseph, C., Gunawan, J., Sawani, Y., Rahmat, M., Noyem, J.A., \& Darus, F. (2016). A comparative study of anti-corruption practice disclosure among Malaysian and Indonesian corporate social responsibility (CSR) best practice companies. Journal of Cleaner Production, 112, 2896-2906.

Kana, S.P. (2020). Corporate governance practice in the context of the political situation in South Africa over the last 25 years. Journal of Global Responsibility, 11(2), 127-137. https://doi.org/10.1108/JGR-10-2019-0100

Kaufmann, D., Kraay, A., \& Mastruzzi, M. (2007). Aggregate governance indicators, 19962006, accessed at: http://info.worldbank.org/governance/wgi2007/

Komolafe, A., Nkereuwem, E., \& Kalu-Amah, O. (2019). Corruption Reporting in the Media in the 2015 Nigerian Elections: Setting the Agenda or Toeing the Line?

https://ace.soas.ac.uk/wp-content/uploads/2019/07/ACE-WorkingPaper011-MediaCorruption-Reporting-in-Nigeria-190708.pdf

Kooiman, J. (1999). Social-Political Governance, Public Management. An International Journal of Research and Theory, 1(1), 67-92, DOI:10.1080/14719037800000005

Lexology (2016). EFCC investigates misappropriation of funds. Sofunde Osakwe Ogundipe \& Belgore, Dasukigate. https://www.lexology.com/library/detail.aspx?g=53a5b018-023747a6-a896-cb153d383b04

McAllister, I. (2014). Corruption and confidence in Australian political institutions", Australian Journal of Political Science, 49(2), 174-185.

DOI:10.1080/10361146.2014.880401

Madichie, N. O. (2005). Corruption in Nigeria: how effective is the corruption perception index in highlighting the economic Malaise? World Review of Science, Technology and Sustainable Development, 2(3/4), 320-337

Martini, M. (2014). Nigeria: Evidence of corruption and the influence of social norms, Transparency International, No. 2014:20

https://www.transparency.org/files/content/corruptionqas/Nigeria_overview_of_corruption_a nd_influence_of_social_norms_2014.pdf

Montero, D. (2018). How Managers Should Respond When Bribes Are Business as Usual", Harvard Business Review [Online] November 16 2018. https://hbr.org/2018/11/howmanagers-should-respond-when-bribes-are-business-as-usual

Mordi, R. (2016). Is Buhari's anti-corruption war selective? The Nation, 13 July http://thenationonlineng.net/buharis-anti-corruption-war-selective/

New York Times (2015). Diepreye Alamieyeseigha, Nigerian Notorious for Corruption, Dies at 62. https://www.nytimes.com/2015/10/15/world/diepreye-alamieyeseigha-nigerian-exgovernor-dies-at-62.html 
Nigeria LII, National Judicial Institute (2016). Kalu Vs Federal Republic Of Nigeria and Others, (SC.215/2012) [2016] NGSC 34 (18 MARCH 2016).

https://nigerialii.org/ng/judgment/supreme-court/2016/34

Nigeria Tribune (2020). EFCC Set for Fresh, Immediate Retrial Of Orji Uzor Kalu, By Saliu Gbadamosi -Abuja On May 8, 2020 https://tribuneonlineng.com/efcc-set-for-freshimmediate-retrial-of-orji-uzor-kalu/

Ochulor, C.L. (2011). Failure of Leadership in Nigeria. American Journal of Social and Management Sciences, 2(3), 265-271.

Okolie, U. C., Igwe, P. A., \& Elom, E. N. (2019). Improving graduate outcomes for technical colleges in Nigeria. Australian Journal of Career Development, 28(1), 21-30.

doi: $\underline{10.1177 / 1038416218772189}$

Okoye, R. (2012). Nigeria has lost \$400bn oil revenue to corruption since Independence Ezekwesili, Daily Post Newspaper, August 31, 2012. https://dailypost.ng/2012/08/31/nigerialost-400bn-oil-revenue-corruption-since-independence-ezekwesili/

Onyema, E., Roy, P., Oredola, H., \& Ayinla, S. (2018). The Economic and Financial Crimes Commission and the politics of (in) effective implementation of Nigeria's anti-corruption policy, Anti-corruption Evidence Working Paper 007.

https://eprints.soas.ac.uk/31283/1/ACE-WorkingPaper007-EFCC-Nigeria.pdf

Peters, A. (2018). Corruption as a Violation of International Human Rights, European Journal of International Law, 29(4), 1251-1287 https://doi.org/10.1093/ejil/chy070

Premuim Times (2020). Alleged 100bn fraud: We'll reopen Odili's corruption case, says Magu. January 8 2020. https://www.premiumtimesng.com/news/more-news/371697-alleged100bn-fraud-well-reopen-odilis-corruption-case-says-magu.html

Punch (2017). Ibori receives rousing welcome in Oghara. Feb 4, 2017 https://punchng.com/ibori-receives-rousing-welcome-oghara/

Quartz Africa (2016). A \$31 million scandal with Nigeria's ex-first lady shows the scale of Buhari's anti-corruption battle. September 15 2016. https://qz.com/africa/781920/a-31million-scandal-with-nigerias-ex-first-lady-shows-the-scale-of-buharis-anti-corruption-battle/

Romain P. L. (2015). Conflicts of interest in research: looking out for number one means keeping the primary interest front and center", Current reviews in musculoskeletal medicine, 8(2), 122-127. https://doi.org/10.1007/s12178-015-9270-2

Rossouw, G. J. (2005). Business Ethics and Corporate Governance in Africa. Business \& Society, 44(1), 94-106. doi: 10.1177/0007650305274851.

Rossouw, G. J. (2020). The ethics of governance and governance of ethics in the King Reports", Journal of Global Responsibility, 11(2), 187-196 DOI 10.1108/JGR-10-2019-008

Sanni, K. (2020). At least N9.4bn paid as bribe for justice in Nigeria in two years - ICPC Report. Premium Times, Dec. 26, 2020.

https://www.premiumtimesng.com/news/headlines/433257-at-least-n9-4bn-paid-as-bribe-forjustice-in-nigeria-in-two-years-icpc-report.html 
Steytler, N. (2020). Towards understanding and combating the crime of corruption in Africa. Corruption and Constitutionalism in Africa. Oxford University Press, New York, USA.

Sulemana, I., Iddrisu, A. M. and Kyoore, J. E (2017). A Micro-Level Study of the Relationship Between Experienced Corruption and Subjective Wellbeing in Africa. The Journal of Development Studies, 53(1), 138-155 DOI: 10.1080/00220388.2016.1187721

Thisday (2016). Two Judges in EFCC Net over Bribes from Lawyers. 18 Oct. 2016. https://www.thisdaylive.com/index.php/2016/10/18/two-judges-in-efcc-net-over-bribes-fromlawyers/

Transparency International (2020a). Nigeria. https://www.transparency.org/en/countries/nigeria

Transparency International (2020b). 25 Corruption Scandals that shocked the world. https://www.transparency.org/en/news/25-corruption-scandals\#Nigeria

Vanguard (2017). Ex Minister loses .... Tower, \$2.7m to Federal Govt. Read more at: https://www.vanguardngr.com/2017/08/diezani-loses-banana-tower-2-7m-federal-govt/

Vanguard (2018). EFCC probes State Government 4 Accounting officials of N117bn cash withdrawal in 3 years. Read more at: https://www.vanguardngr.com/2018/08/efcc-riversgovt-clash-over-alleged-n117bn-fraud/

Vanguard (2020). JAMB revenue officer allegedly stole N36.5m-EFCC witness. March 17, 2020. Read more at: https://www.vanguardngr.com/2020/03/jamb-revenue-officer-allegedlystole-n36-5m-efcc-witness/

Vanguard (2020). Nigerian ex-minister forfeited sum of N426.7 million to the Federal Government on the orders of a Federal judge, sitting in Lagos. Read more at:

https://www.vanguardngr.com/2020/05/army-general-forfeits-n426-7m-to-fg-2/

Wade, R. (1982). The system of administrative and political corruption: Canal irrigation in South India. The Journal of Development Studies, 18(3), 287-328

DOI: $\underline{10.1080 / 00220388208421833}$

Walton, G. W. (2015). Defining Corruption Where the State is Weak: The Case of Papua New Guinea. The Journal of Development Studies, 51(1), 15-31

DOI: $\underline{10.1080 / 00220388.2014 .925541}$

Wieland, J. (2001). The Ethics of Governance. Business Ethics Quarterly, 11(1), 73-87. doi: $10.2307 / 3857870$

Woods, P. A. (2003). Building on Weber to Understand Governance: Exploring the Links Between Identity, Democracy and 'Inner Distance. Sociology, 37(1), 143-163. doi: $10.1177 / 0038038503037001391$

World Economic Forum (2019). Three things Nigeria must do to end extreme poverty”. https://www.weforum.org/agenda/2019/03/90-million-nigerians-live-in-extreme-povertyhere-are-3-ways-to-bring-themout/\#: :text=About\%2090\%20million\%20people\%20\%2D\%20roughly, the\%20bottom\%20of $\% 20$ the $\% 20$ table. 
Yap, O. F. (2013). When do Citizens Demand Punishment of Corruption?" Australian Journal of Political Science, Vol. 48 No. 1, pp. 57-70, DOI: 10.1080/10361146.2012.760525

Figure 1. Qualitative - Content Analysis Process

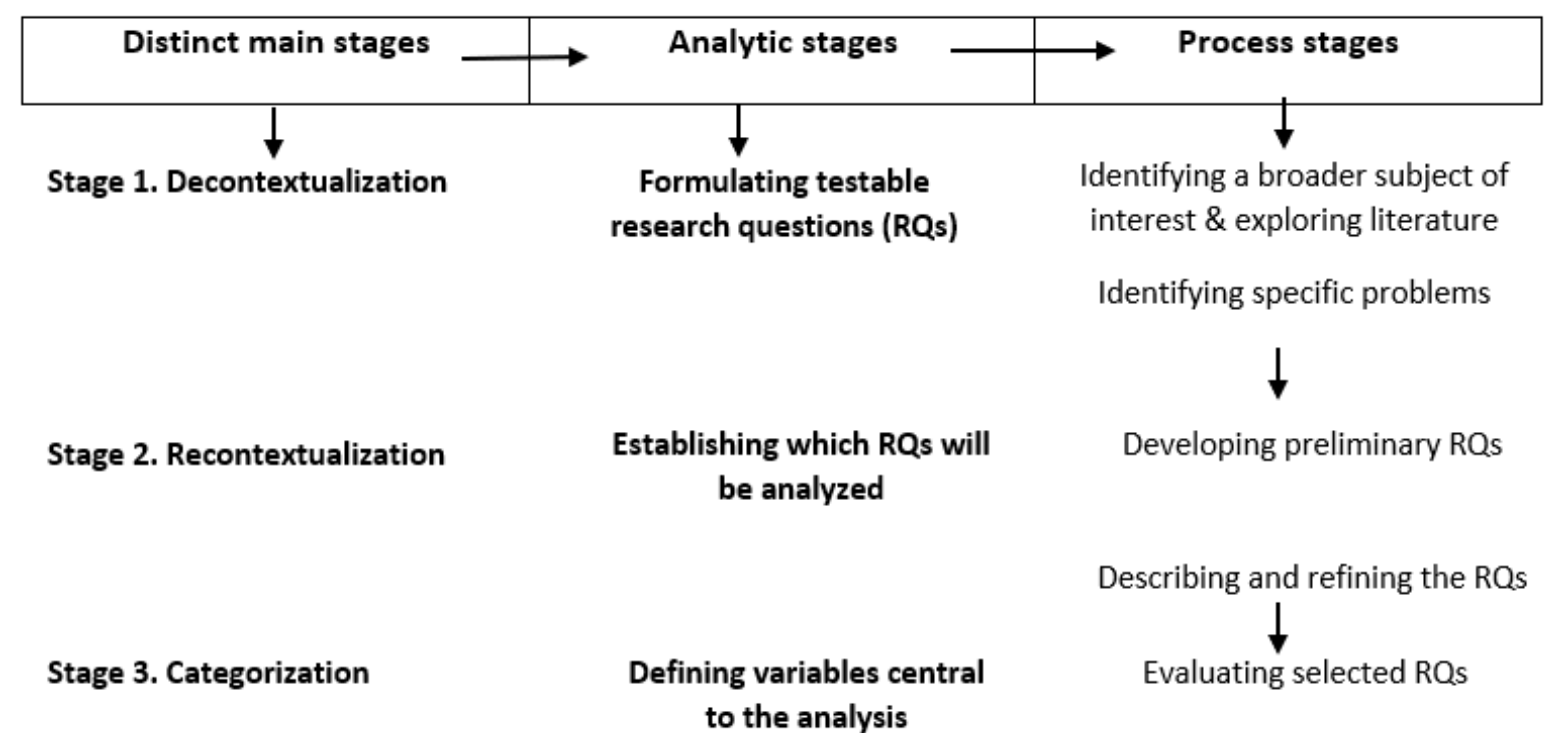

Stage 4. `Compilation

Stage 5. Production to the analysis

Narrowing the scope and focus

\section{Establishing RQs that will be analyzed}

Defining variables central to the analysis

Analyzing selected RQs 
Table 1. EFCC High Profile Court Cases (2006 - 2015)

\begin{tabular}{|c|c|c|c|}
\hline Culprit & Court of Jurisdiction & Amount & Year \\
\hline $\begin{array}{l}\text { A Former Governor in } \\
\text { Western Region States }\end{array}$ & Fed. High Court, Lagos. & N1.2 Billion & 2006 \\
\hline $\begin{array}{l}\text { A Former Governor in the } \\
\text { Northern States }\end{array}$ & FCT High Court Gudu & N700 Million & 2007 \\
\hline $\begin{array}{l}\text { A Former Governor in the } \\
\text { Northern States }\end{array}$ & FCT High Court Maitama & N36 Billion & 2007 \\
\hline $\begin{array}{l}\text { A Former Governor in the } \\
\text { Eastern States and } 2 \text { others }\end{array}$ & Fed. High Court Maitama & N7.65bn & 2007 \\
\hline $\begin{array}{l}\text { A Former Governor in the } \\
\text { Northern States }\end{array}$ & Fed. High Court, Abuja & N1.3 billion & 2007 \\
\hline $\begin{array}{l}\text { A Former Governor in } \\
\text { Eastern States }\end{array}$ & Fed. High Court, Lagos & N5.3 Billion & 2007 \\
\hline $\begin{array}{l}\text { A Former Governor in the } \\
\text { Norther States }\end{array}$ & Fed. High Court, Maitama & N1.5 Billion & 2008 \\
\hline $\begin{array}{l}\text { A Former Minister of } \\
\text { Health }\end{array}$ & FCT. High Court Maitama & N300 million & 2008 \\
\hline $\begin{array}{l}\text { A Former Governor in the } \\
\text { Niger-Delta States }\end{array}$ & Federal High Court Asaba & N9.2 Billion & 2008 \\
\hline $\begin{array}{l}\text { A Former Governor in the } \\
\text { Mid-Western Region }\end{array}$ & Fed. High Court, Enugu & N4.3 Billion & 2008 \\
\hline $\begin{array}{l}\text { A Former Minister of } \\
\text { Health }\end{array}$ & FCT. High Court, Maitama & N300 Million & 2008 \\
\hline $\begin{array}{l}\text { A Former Managing } \\
\text { Director of Federal Agency }\end{array}$ & FCT High Court, Maitama & N5.6 Billion & 2008 \\
\hline $\begin{array}{l}\text { A former Minister of } \\
\text { Aviation }\end{array}$ & FCT High Court, Maitama & N5.6 Billion & 2008 \\
\hline $\begin{array}{l}\text { A former Governor in the } \\
\text { Northern States }\end{array}$ & Fed. High Court Maitama & N254 Million & 2008 \\
\hline $\begin{array}{l}\text { A former Minster of } \\
\text { Aviation }\end{array}$ & Fed. High Court, Lagos & N250 Million & 2008 \\
\hline $\begin{array}{l}\text { A Contractor - Police } \\
\text { Equipment Fund }\end{array}$ & FCT High Court, Abuja & N774 Million & 2008 \\
\hline $\begin{array}{l}\text { A Former Governor in the } \\
\text { Western States }\end{array}$ & Fed. High Court, Lagos & N6 Billion & 2008 \\
\hline $\begin{array}{l}\text { Chieftain of a major } \\
\text { political party }\end{array}$ & Fed. High Court. Lagos & N100 Billion & 2009 \\
\hline 4 Senior Bank Managers & $\begin{array}{l}\text { Fed. High Court, Port } \\
\text { Harcourt }\end{array}$ & N3.6 Billion & 2009 \\
\hline $\begin{array}{l}\text { Some Senators, Members of } \\
\text { House of Representatives } \\
\text { and Serving Fed. Perm. Sec }\end{array}$ & FCT High Court Abuja & N5.2 Billion & 2009 \\
\hline $\begin{array}{l}\text { Nigeria Electricity } \\
\text { Regulatory Commission } \\
\text { case }\end{array}$ & Federal High Court, Abuja & N1.5 Billion & 2009 \\
\hline $\begin{array}{l}\text { GM \& Managers of ... } \\
\text { Group PLC }\end{array}$ & Fed. High Court, Abuja & N15 Billion & 2009 \\
\hline
\end{tabular}




\begin{tabular}{|l|l|l|l|}
\hline $\begin{array}{l}\text { Directors of Federal } \\
\text { Agency- NGA }\end{array}$ & FCT High Court, Lugbe & N1.012 Billion & 2009 \\
\hline $\begin{array}{l}\text { Ex. Sec. National } \\
\text { Commission for Mass } \\
\text { Literacy, Adult \&Non- } \\
\text { Formal Education }\end{array}$ & Fed. High Court, Abuja & N479 Million & 2009 \\
\hline $\begin{array}{l}\text { Ex. CG Customs and } \\
\text { Director of Private company }\end{array}$ & Fed. High Court, Lagos & N2.5 Billion & 2009 \\
\hline $\begin{array}{l}\text { Founder/ CEO [.....] Bank } \\
\text { PLC }\end{array}$ & FHC, Ikoyi, Lagos. & N160.2 Billion & 2009 \\
\hline CEO [....] Bank PLC & FHC, Ikoyi, Lagos & N187.1 Billion & 2009 \\
\hline $\begin{array}{l}\text { Chairman [...] Bank PLC } \\
\text { and others }\end{array}$ & FHC, Ikoyi, Lagos & N131.8 Billion & 2009 \\
\hline $\begin{array}{l}\text { MD and 2 others [Security] } \\
\text { Co. }\end{array}$ & FHC, Ikoyi, Lagos. & N277.3 Billion & 2009 \\
\hline Private Firm & FHC, Ikoyi, Lagos & N95.1 Billion & 2009 \\
\hline $\begin{array}{l}\text { Ex-Bank Manager \& } \\
\text { Company Director }\end{array}$ & Lagos High Court, Ikeja & N860 Million & 2009 \\
\hline A Former CEO, [...] Bank & Fed High Court, Lagos & N80 billion & 2009 \\
\hline $\begin{array}{l}\text { A Former Governor in the } \\
\text { Norther States }\end{array}$ & Fed High Court, Lafi & N15 billion & 2010 \\
\hline $\begin{array}{l}\text { A former governor in the } \\
\text { Northern States }\end{array}$ & Sokoto state High Court. & N15 billion & 2010 \\
\hline $\begin{array}{l}\text { Accountant General in the } \\
\text { Niger Delta States }\end{array}$ & Fed. High Court, Abuja & N2.4 billion & 2010 \\
\hline $\begin{array}{l}\text { A former national security } \\
\text { adviser and four others }\end{array}$ & $\begin{array}{l}\text { FCT High Court, sitting in } \\
\text { Maitama, }\end{array}$ & N13.57 billion & 2015 \\
\hline
\end{tabular}

Note: This table has been compiled from desk research and from various sources and do not capture all the EFCC corruption cases. For full list of EFCC current and past cases [see, http://www.efccnigeria.org/efcc/public-notices] 